\title{
Interference of Environmental Factors with Temperature Effects on Plant Growth
}

\author{
III. Light Intensity \\ Tsuyoshi MATSUI,* Yasuhiko SOEJIMA,* and Hiromi EgUCHI* \\ *Biotron Institute, Kyushu University, Fukuoka, Japan
}

(Received October 7, 1972)

\begin{abstract}
To analyze the interference of light intensity with the effect of temperature on plant growth and other plant responses, the hypocotyl elongation of cucumber seedlings (Cucumis sativus $\mathrm{L}$. "Aofushinari") was examined under light intensities of 4,000, 8,000 and 12,000 lux for 8-hour photoperiods at air temperatures of $20,25,30,35$ and $40^{\circ} \mathrm{C}$ in a growth cabinet. Cucumber seedlings were sown in a plastic container filled with burnt chaff. One day after germination, the seedlings were cultured under their respective light intensities and following results were obtained:

1) Hypocotyl elongation was remarkably affected by light intensity at different temperatures; hypocotyl elongation was inhibited by increased light intensities.

2) The effect of light intensity on the hypocotyl elongation was greatest at $30^{\circ} \mathrm{C}$ and smallest at $20^{\circ} \mathrm{C}$.

3) The optimum temperature for hypocotyl elongation was altered by changing the light intensity; at a light intensity of $4,000 \mathrm{lux}$, the optimum temperature was $30^{\circ} \mathrm{C}$ and at 8,000 and 12,000 lux, the optimum temperature was $35^{\circ} \mathrm{C}$.

From these results, it is clear that the effect of temperature on hypocotyl elongation of cucumber seedlings is remarkably affected by light intensity. This suggests that much more importance should be attached to light intensity conditions for the exact analyses of the effect of temperature on the plant growth and other plant responses.
\end{abstract}

There are many variables in most of the controlled environments. It may be considered that some uncontrolled factors affect plant growth and differentiation and prevent the exact analysis of the effect of temperature on plant responses. ${ }^{3,4)}$ It is important, therefore, to know to what extent these factors affect the plant responses to the temperature. Light conditions, such as light intensity, light quality and photoperiod should be considered important factors.

In a phytotron glass room, light conditions are variable, daily and seasonal changes occur in the natural light. Accordingly plant responses to temperature would be not constant even under the controlled air-temperature condi tions.
Present paper deals with the analyses of the interference of light intensity with the effect of temperature on hypocotyl elongation of cucumber seedlings.

\section{MATERIALS AND METHODS}

Cucumis sativus L. "Aofushinari" was used in this study. Seeds were sown in a plastic container filled with burnt chaff used as a root supporter. The bottom of the container was kept in water to moister in the burnt chaff. Seeds were germinated at $25^{\circ} \mathrm{C}$ and one day after germination, the hypocotyl unit ${ }^{1,2}$ was marked with indian ink at the cotyledonary node and at a distance $10 \mathrm{~mm}$ below the cotyledonary 
node. Hypocotyl elongation was examined by measuring the change of the hypocotyl unit lengths, using the 10 seedlings.

The growth cabinet was used to control the air temperature, air humidity and carbon dioxide gas concentration. The air temperatures were controlled at $20,25,30,35$ and $40^{\circ} \mathrm{C}$ with an accuracy of $\pm 0.5^{\circ} \mathrm{C}$. The air humidity was controlled at constant relative humidity of $60 \pm$ $3 \%$. The carbon dioxide gas concentration was fixed at $320 \mathrm{ppm}$. Fluorescent lamps (FLR 40S. $\mathrm{W}-\mathrm{SDL}-\mathrm{AP} / \mathrm{M}$ ) were used as the light source, and their intensities were adjusted to 4,000 , 8,000 and 12,000 lux by increasing the number of the fluorescent lamps.

\section{RESULTS AND DISCUSSIONS}

Figures 1 and 2 show the hypocotyl unit elongation curves of cucumber seedlings under

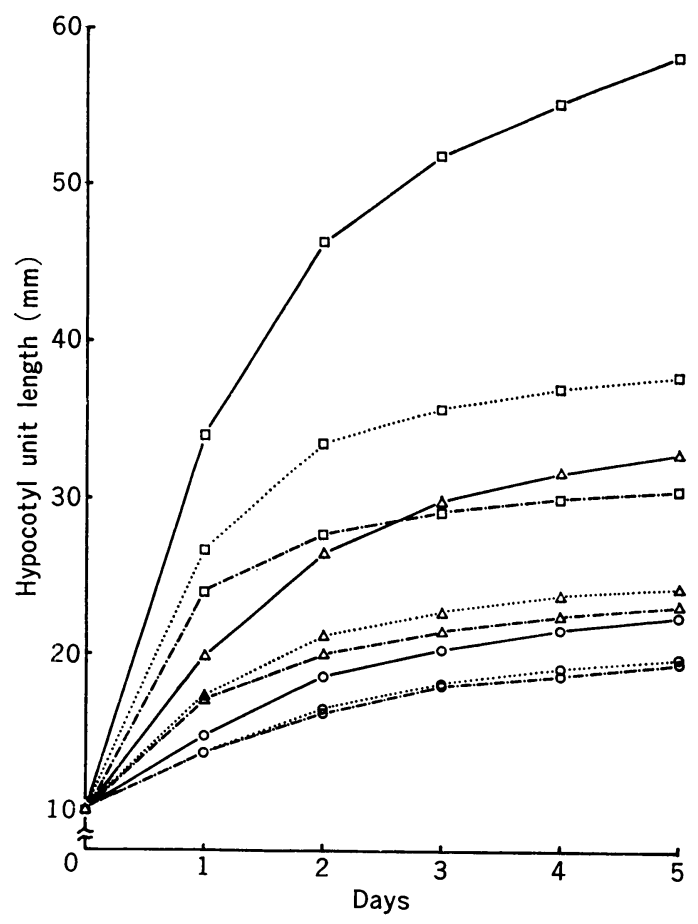

Fig. 1 Hypocotyl elongation curves of cucumber seedlings under the different light intensities at the respective air temperatures of 20,25 and $30^{\circ} \mathrm{C}$.
○ $20^{\circ} \mathrm{C}$,
- 4,000 lux,
$\triangle 25^{\circ} \mathrm{C}, \quad \cdots \cdots \ldots .6,000$ lux,
$\square 30^{\circ} \mathrm{C}$. -... 12,000 lux.

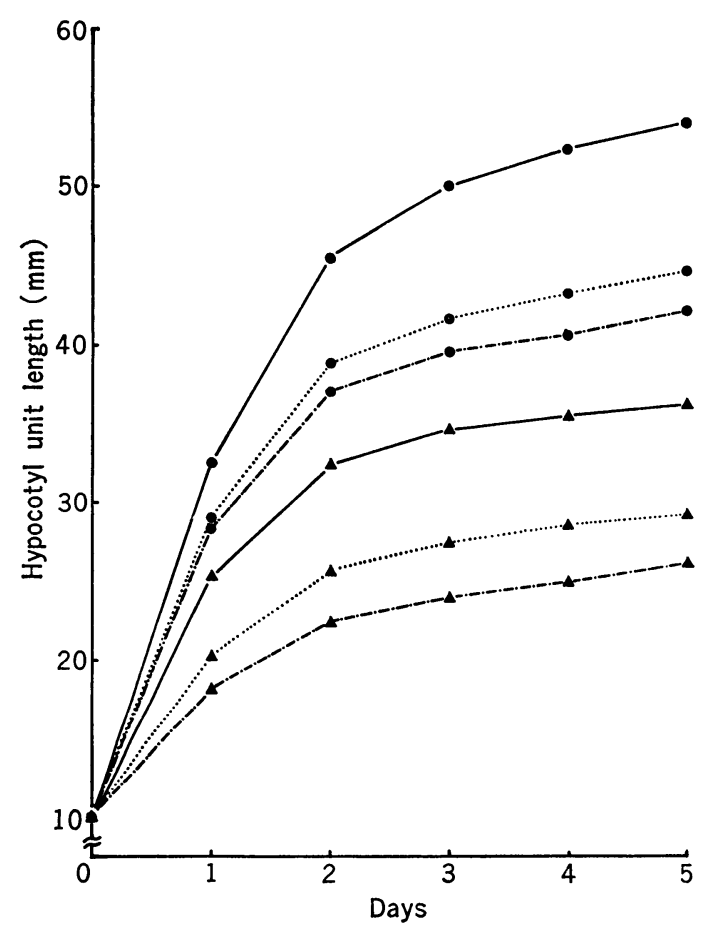

Fig. 2 Hypocotyl elongation curves of cucumber seedlings under the different light intensities at the respective air temperatures of 35 and $40^{\circ} \mathrm{C}$.

$\begin{array}{lll}\text { - } 35^{\circ} \mathrm{C}, & & \\ \text { ^ } 40^{\circ} \mathrm{C} . & \ldots \ldots . . & 4,000 \mathrm{lux}, \\ & \ldots, 000 \mathrm{lux},\end{array}$

light intensities of 4,000, 8,000 and 12,000 lux at the respective air temperatures of $20,25,30$, 35 and $40^{\circ} \mathrm{C}$. The hypocotyl elongation was greatly affected by the air temperatures and also the light intensities. The effect of light intensities was inhibited by increased light intensities at the respective temperature conditions. For example, during first 2 days, hypocotyl elongation under the condition of $30^{\circ} \mathrm{C}$ 12,000 lux was larger than that under the condition of $25^{\circ} \mathrm{C}-4,000$ lux, however, at 3 days after the treatment, it became smaller than that under the condition of $25^{\circ} \mathrm{C}-4,000$ lux.

Figure 3 shows the comparison of the sensitivities of hypocotyl elongation to light intensity under different air temperature conditions, using the hypocotyl unit lengths of the 5th day. The sensitivities of hypocotyl elongation to light intensity were altered by the air temperature conditions; the sensitivity was highest at $30^{\circ} \mathrm{C}$ and lowest at $20^{\circ} \mathrm{C}$.

Environ. Control in Biol. (生物環境調節) 


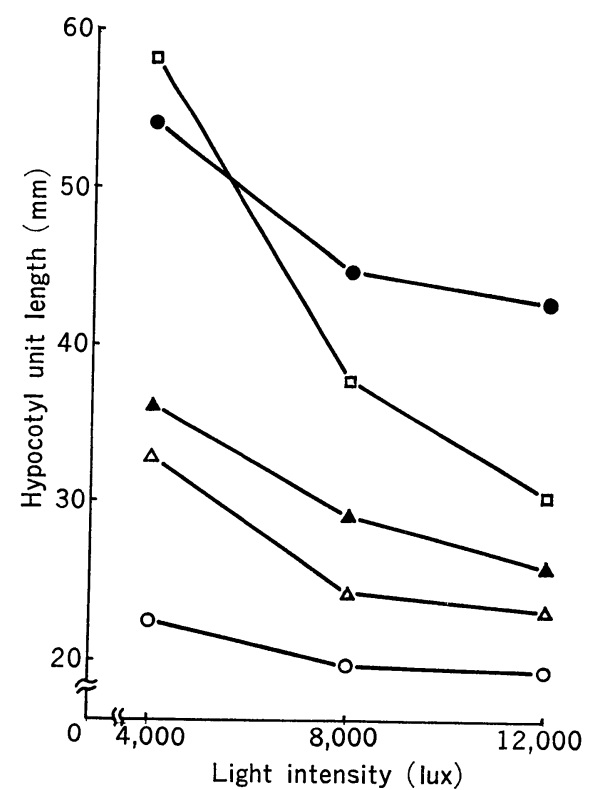

Fig. 3 Comparison of the sensitivities of hypocotyl elongation to the light intensity under the different conditions of temperature.

$\bigcirc-\bigcirc 20^{\circ} \mathrm{C}, \triangle-\triangle 25^{\circ} \mathrm{C}, \square-\square 30^{\circ} \mathrm{C}$,

$\bullet-35^{\circ} \mathrm{C}, \Delta-\Delta 40^{\circ} \mathrm{C}$

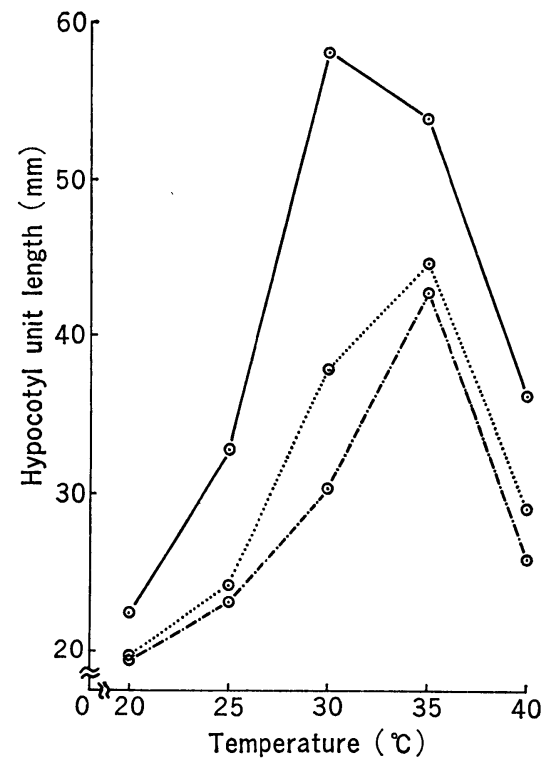

Fig. 4 The effect of light intensities on the hypocotyl elongation under the respective temperatures of $20,25,30,35$ and $40^{\circ} \mathrm{C}$.

$\odot$ —— 4,000 lux, $\odot \ldots . . \odot 8,000$ lux, $\odot-\cdot-\odot 12,000$ lux.
Figure 4 shows the hypocotyl unit lengths on the 5th day under the respective light intensity conditions at air temperatures of 20,25 , 30,35 and $40^{\circ} \mathrm{C}$. The optimum temperature for hypocotyl elongation was $30^{\circ} \mathrm{C}$ at a light intensity of 4,000 lux, while, it was $35^{\circ} \mathrm{C}$ at light intensities of 8,000 and 12,000 lux. This fact shows that the optimum temperature for hypocotyl elongation was clearly shifted from $30^{\circ} \mathrm{C}$ to $35^{\circ} \mathrm{C}$ by changing the light intensity from 4,000 lux to 12,000 lux.

Figure 5 shows the comparison of the effect of temperature on hypocotyl elongation, using the ratio of the hypocotyl unit lengths at 5 days under the different light intensity conditions. Appreciable differences were found in the effect of temperature under the respective light intensity conditions. The temperature effect on the hypocotyl elongation under a light intensity of 4,000 lux was greatest and that under 12,000 lux was smallest.

From these results, it is clear that the effect of temperature on the hypocotyl elongation of cucumber seedlings is remarkably affected by the light intensities. In fact, there are daily and seasonal variations of the light intensity under natural light conditions such as in phytotron

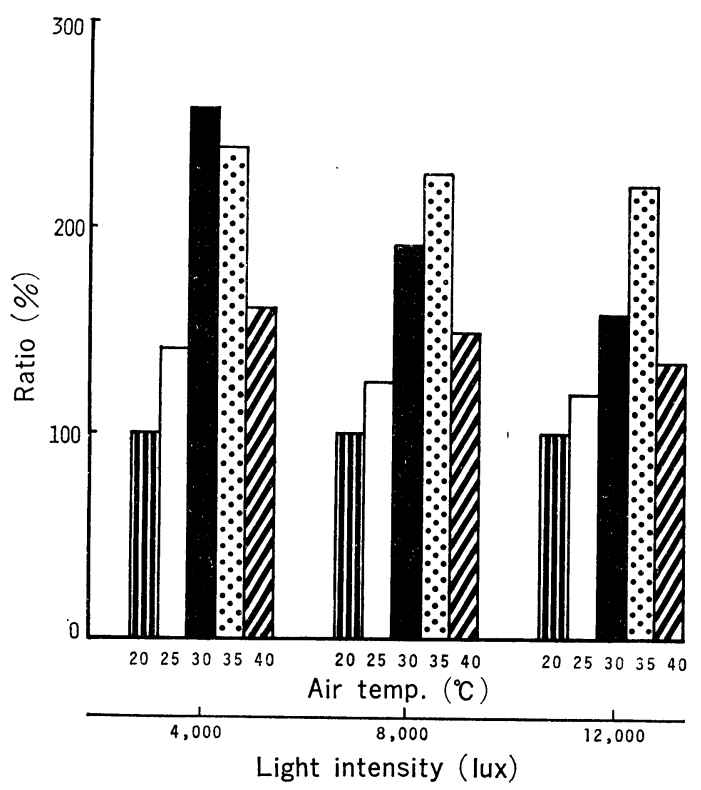

Fig. 5 Comparison of temperature effect on hypocotyl elongation on the 5 th day under the respective light intensities of $4,000,8,000$ and 12,000 lux. 
glass rooms. From these facts, it could be estimated that these variations in light condition bring about complicated effects on plant growth and differentiation. Therefore, much more importance should be attached to light intensity conditions for the exact analyses of the temperature effect on the plant growth and other plant responses.

\section{REFERENCES}

(1) Katsumi, M., Phinney, B. O. and Purves, W. K. 1965 The roles of gibberellin and auxin in cucumber hypocotyl growth. Physiol. Plant. 18, 462-478.

(2) Matsui, T., Eguchi, H. and Hamakoga, M.
1971 Influence of temperature effects of growth regulators on hypocotyl elongation. Environ. Control in Biol. 8, 97-100.

(3) Matsui, T., Kusanagi, T. and Eguchi, H. 1971 Interference of environmental factors with temperature effects on plant growth (I) Root supporters. ibid. 8, 106-110.

(4) Matsui, T., Eguchi, H. and Hamakoga, M. 1972 Interference of environmental factors with temperature effects on plant growth (II) Soil temperature. ibid. 10, 58-62.

(5) Matsui, T., Soejima, Y. and Eguchi, H. 1972 Biological analyses of light characteristics in the artificial light room. (I) Growth analyses of spinach plant under several kinds of light conditions. ibid. 10, 73-79.

<和文抄録 $>$

植物生育に対する温度効果に干涉する環境要因について

III. 光 強 度

松井 健・副島泰彦・江口弘美

九州大学生物環境調節センター

温度制御環境を用いて植物生育に対する温度効果を詳細に解析する場合, 種々の環境要因が温度 効果にいかなる影響をおよぼすかを解明しておく必要がある．本報では各空気温度条件下で異なっ た光強度条件を設定し，キュウリ肧軸伸長に対する光強度の影響を解析した．環境条件設定にはグ ロースキャビネットを用い空気温度 $20,25,30,35,40^{\circ} \mathrm{C}$ とし, 光強度をそれぞれ $4,000,8,000$, 12,000 lux に設定した. 光源としては螢光ランプ (FLR 40S•W-SDL-AP/M) を用い，8時間日 長とした.

1）胚軸伸長は空気温度条件に著しく影響されたが，同時に光強度にも影響された．同一温度条件 では光強度が小であるほど衃軸伸長が大であり，その光強度の効果は温度条件により異なった。

2）光強度に対する胚軸伸長の感受性は温度条件によって異なり， $30^{\circ} \mathrm{C}$ で最大で, $20^{\circ} \mathrm{C}$ で最小で あった。

3）肧軸伸長に対する最適温度は光強度条件によって異なり，キュウリ肧軸伸長は，4,000 lux 区 では $30^{\circ} \mathrm{C}$ で最大で， 8,000 lux および 12,000 lux 区では $35^{\circ} \mathrm{C}$ で最大であった.

ファイトトロンガラス室では光条件, すなわち光強度, 光質, 日長が日周的および季節的に著し く変動しており，このような変動する光条件下では植物生育に対する温度効果が精密に解析できな 、場面がある. 本実験における結果は植物反応に対する温度効果を解析する場合には，これら光要 因の変動を十分考慮に入れる必要があることを示唆しており，人工照明による一定の光条件設定が 温度効果解析に有効な場面が多いことを示している. 